\title{
PEMANFAATAN TUMBUHAN APU-APU (Pistia stratiotes) UNTUK MENUMBUHKAN MAGGOT (Hermetia illucens) SEBAGAI PAKAN IKAN
}

\author{
(Utilization Of Plant Apu-Apu (Pistia stratiotes) For Growing Maggot (Hermetia illucens) \\ As Fish Feed)
}

\author{
Infa Minggawati, Lukas, Youhandy, Yusanti Mantuh, Tania Serezova Augusta \\ Fakultas Perikanan Universitas Kristen Palangka Raya, Kalimantan Tengah, Indonesia, \\ E-mailInfa41@gmail.com
}

Article Submitted : 02-01-2019

Article Accepted : 26-01-2019

\begin{abstract}
The purpose of this study was to determine the effect of different composition of plant apu (Pistia stratiotes) for growing maggot (Hermetia illucens) as feed fish. Research conducted from April to June 2018, with experimental research methods using Complete Randomized Design. The results showed that treatment $A$ with an average growth weight of maggot $=89.6$ grams and 645 populations was higher than treatment B and C. Treatment A composition of $5 \mathrm{~kg}$ of dried apu, 5 $\mathrm{kg}$ of bran, 1,5 liters of wine, 1 liter of honey and 5 eggs. The results of ANOVA diversity analysis and BNT test for maggot growth population showed that the three treatments were significantly different. The novelty of this study is the use of $P$. stratiotes aquatic plants as a place to grow maggots and the fermentation process with wine.
\end{abstract}

Keyword : Composition, Pistia stratiotes, maggot, fish feed

\section{PENDAHULUAN}

Berbagai macam cara dilakukan untuk meningkatkan produksi ikan, salah satunya adalah dengan melakukan riset untuk menciptakan pakan yang ekonomis dengan nilai nutrisi yang sesuai kebutuhan nutrisi ikan. Selama ini bahan baku yang digunakan sebagai bahan baku pakan adalah tepung ikan yang diimpor. Harga tepung ikan yang semakin meningkat tidak diikuti dengan harga ikan yang relatif stabil di pasaran, terutama ikan air tawar yang harganya lebih terjangkau dibandingkan ikan air laut.

Hal ini tentu menjadi perhatian lebih pemerintah dan para petani dimana untuk memproduksi satu kilogram ikan dibutuhkan biaya pakan sebesar 50-70 \% dari biaya produksi (Sahwan, 2003). Untuk menekan biaya pakan, dilakukan berbagai riset yang bertujuan mencari bahan baku alternatif pengganti tepung ikan, dan bahan baku alternatif tersebut diutamakan bahan baku lokal yang selalu tersedia. Salah satu bahan baku yang dapat digunakan sebagai pakan ikan adalah maggot (Hermetia illucens).

Maggot merupakan organisme yang berasal dari telur black soldier yang dikenal sebagai organisme pembusuk karena kebiasaannya mengkonsumsi bahan-bahan organik (Tomberlin, 2009).. Syarat bahan yang dapat dijadikan bahan baku pakan yaitu, tidak berbahaya bagi ikan, tersedia sepanjang waktu, mengandung nutrisi sesuai dengan kebutuhan ikan, dan bahan tersebut tidak berkompetisi dengan kebutuhan manusia.

Berdasarkan persyaratan tersebut, maka maggot dapat dijadikan bahan baku alternatif penganti tepung ikan sebagai bahan 
baku pakan. Maggot dapat tumbuh dan berkembang pada media yang mengandung nutirisi yang sesuai dengan kebutuhan hidupnya. Budidaya maggot dapat dilakukan dengan menggunakan media yang mengandung bahan organik dan berbasis limbah ataupun hasil samping kegiatan agroindustri. Oleh karena itu, untuk menunjang budidaya maggot, perlu diketahui media yang optimal bagi pertumbuhan dan perkembangbiakan maggot. Menurut Azir A, $d k k$ (2017), bahwa pada saat ini media tumbuh manggot yang paling baik adalah menggunakan bungkil kelapa sawit, namun demikian budidaya maggot masih dapat ditumbuhkan dengan baik pada media limbah pasar yang berupa limbah industri pertanian dan perikanan.

Handajani (2011) menyebutkan bahwa maggot dapat menggantikan tepung ikan sebanyak 30\%. Sedangkan Sheppard dan Newton (1999) dalam Sugianto (2007) menyebutkan bahwa maggot bisa menggantikan tepung ikan kualitas tinggi dan memberikan pertumbuhan yang sama walaupun diberikan dengan kondisi larva yang dipotong-potong

Habitat hidup maggot adalah daerah yang lembab, bersuhu sedang dan tidak terkena cahaya matahari secara langsung. Untuk bisa membudidayakan maggot diperlukan media dan tempat yang sesuai dengan hidup maggot. Kondisi untuk tampat budidaya harus minim cahaya atau bersuhu sedang dengan aroma yang khas agar bisa mengundang lalat untuk datang dan dapat bertahan hidup sampai bertelur (Hartono dan Sukardi, 2007). Sumber nutrisi yang baik digunakan untuk menumbuhkan maggot adalah yang banyak mengandung bahan organik (DoPonte, 2003).

Apu-apu (Pistia stratiotes) merupakan bahan baku pakan lokal dengan serat, nilai nutrien dan produksi biomassa bahan kering yang cukup tinggi. Tanaman ini, dapat berpotensi sebagai bahan penyusun pakan. Tujuan dari penelitian ini adalah pengaruh permentasi tumbuhan apu-apu (Pistia stratiotes) untuk media tumbuh maggot (Hermetia illucens) sebagai pakan ikan. Sehingga di peroleh populasi maggot yang memiliki nilai produksi tinggi sebagai alternatif pakan alami pada ikan.Manfaat dari penelitian ini adalah memberikan informasi kepada masyarakat sekitar, khususnya Kalimantan Tengah mengenai pakan hasil fermentasi tumbuhan apu-apu (Pistia stratiotes) sebagai media tumbuh maggot (Hermetia illucens) untuk alternatif pakan alami pada ikan.

\section{METODE PENELITIAN}

Penelitian ini dilaksanakan selama tiga bulan, mulai bulan April 2018 sampai dengan bulan Juni 2018. Lokasi kegiatan penelitian rumah tempat pembuatan pakan ikan Fakultas Perikanan Program Studi Budidaya Perairan Universitas Kriaten Palangka Raya. Metode penelitian ini adalah penelitian eksperimenen dengan menggunakan Rancangan Acak Lengkap (RAL) yang terdiri dari tiga perlakuaan (A,B dab C) dan tiga ulangan (1, 2 dan 3). Masingmasing perlakuan terdiri dari komposisi bahan yang berbeda untuk menumbuhkan maggot, yaitu : Perlakuan A terdiri dari apuapu kering $5 \mathrm{~kg}$, dedak $5 \mathrm{~kg}$, tuak 1,5 liter, madu 1 liter dan 5 butir telor ayam ; perlakuan B apu-apu kering $6 \mathrm{~kg}$, dedak 3,5 $\mathrm{kg}$, tuak 1 liter, madu 0,7 liter dan 5 butir telor ayam ; perlakuan $\mathrm{C}$ apu-apu kering $7 \mathrm{~kg}$, dedak 2,5 kg, tuak 0,5 liter, madu 0,5 liter dan 5 butir telur ayam.

\section{HASIL DAN PEMBAHASAN}

\section{Populasi dan Pertumbuhan Maggot}

Berdasarkan hasil pengamatan setelah 15 hari di lakukan panen, pertumbuhan populasi maggot (Hermetia illuciens) di media apu-apu dengan komposisi yang berbeda maka di peroleh maggot dengan panjang $1,5 \mathrm{~cm}$ dengan berat rata-rata 0,125 gram per ekor. 


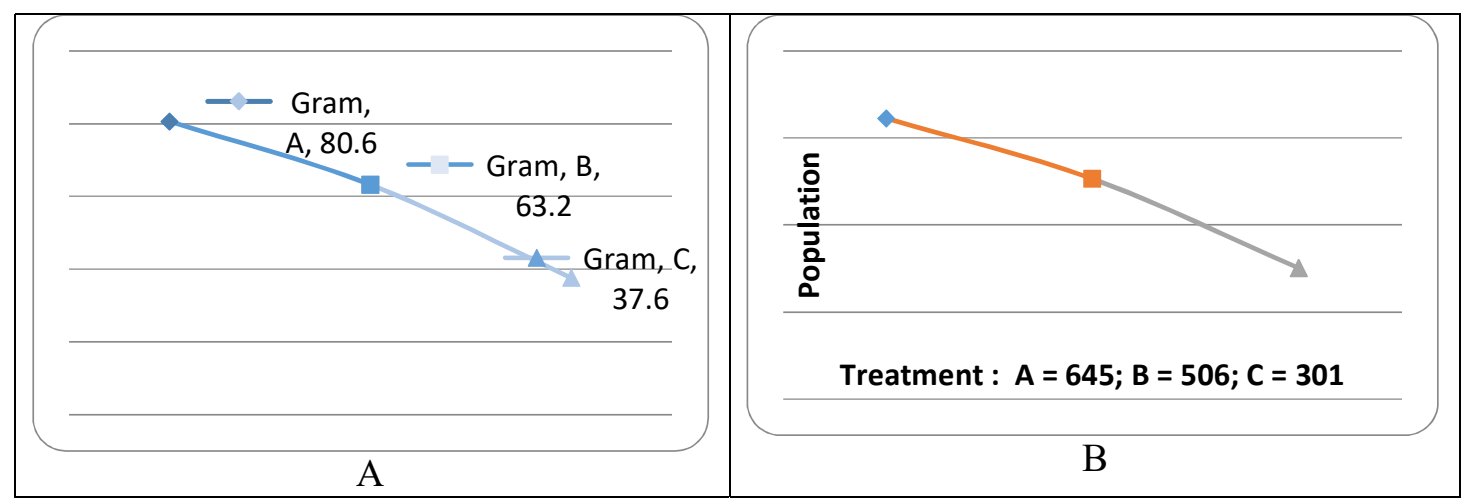

Gambar 1. A. Grafik Rata-rata Berat (gram) Maggot; B. Grafik Rata-rata Populasi Maggot.

Dari grafik pada Gambar 1 A, terlihat bahwa berat rata-rata pertumbuhan populasi maggot perlakuan $A=80,6$ gram, perlakuan $\mathrm{B}=63,2$ gram dan perlakuan $\mathrm{C}=37,6$ gram. Perlakuan A memiliki berat rata-rata yang tinggi dibandingkan dengan perlakuan $\mathrm{B}$ dan C. Perlakuan A dengan komposisi yaitu, apu-apu kering $5 \mathrm{~kg}$, dedak $5 \mathrm{~kg}$, tuak 1,5 liter, madu 1 liter dan 5 butir telur ayam.
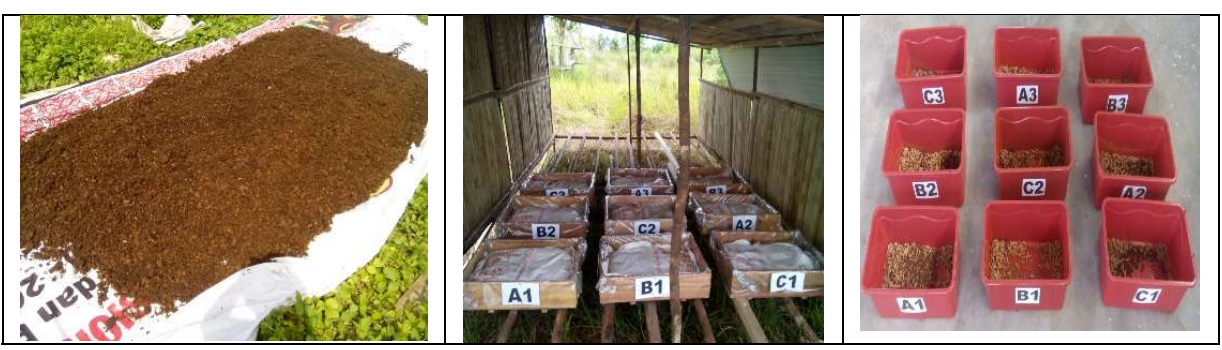

Gambar 2. Proses Penjemuran tumbuhan apu-apu (Pistia stratiotes), Bak Budidaya Maggot dan Populasi Maggot dari masing-masing Perlakukan

Dari grafik pada Gambar 2 terlihat bahwa jumlah populasi maggot perlakuan $\mathrm{A}=$ 645 ekor, perlakuan $\mathrm{B}=506$ ekor dan perlakuan $\mathrm{C}=301$ ekor. Perlakuan A memiliki jumlah populasi rata-rata yang lebih tinggi bila dibandingkan dengan perlakuan B dan C. Perlakuan A dengan komposisi yaitu, apu-apu kering $5 \mathrm{~kg}$, dedak $5 \mathrm{~kg}$, tuak 1,5 liter, madu 1 liter dan 5 butir telur ayam. Proses fermentasi pada perlakuan A cukup baik karena menghasilkan populasi maggot yang tinggi dan pertumbuhan maggot yang lebih cepat. Hal yang mempengaruhi produksi budidaya maggot adalah kondisi media, lingkungan budidaya, dan kandungan nutrisi bahan tumbuh maggot. Maggot menyukai kondisi lingkungan yang lembab dan minim cahaya dan memiliki kandungan nutrisi yang cukup tinggi. Media tumbuh maggot memiliki kadar air yang rendah dengan suhu rata-rata $37,6^{0} \mathrm{C}$, setelah beberapa hari media pertumbuhan maggot akan mengeluarkan aroma bau yang menyengat karena kondisi media yang sudah terjadi pembusukan serta berwarna coklat kehitaman.

Berdasarkan hasil uji kandungan proksimat maggot yang telah dibuat menjadi tepung maggot memiiliki kandungan air $0,96 \%$, protein $50,34 \%$, dan lemak $40,92 \%$. Nilai protein maggot dari hasil penelitian ini lebih tinggi bila dibandingkan dengan kandungan protein maggot dari penelitian 
Saurin (2005) dan Retnosari (2007), yang berkisar $42 \%$.

Tumbuhan apu-apu, dapat berpotensi sebagai bahan penyusun pakan, karena berdasarkan berat kering mengandung BETN $37,0 \%$, protein kasar $19,5 \%$, kadar abu $25,6 \%$, lemak kasar 1,3\% dan mengandung serat kasar 11,7\% (Yudhitstira 2013). Menurut Murni et al. (2008), dedak mengandung nutrisi sebagai berikut yaitu protein kasar $12-14 \%$, kadar lemak 7-19\%, kadar abu 9-12\%, serat kasar 8-13\%, dan BETN 64-42\%. Kandungan nutrient ini yang merangsang Black soldier untuk berproduksi di media yang telah disediakan. Madu adalah campuran dekstrosa dan fruktosa dengan jumlah yang sama dan dikenal sebagai gula invert $50-90 \%$ dari gula yang tidak terintervensi dan air. (Songbesan, 2015).

Menurut Doponte (2003), kandungan nutrisi dari budidaya maggot juga akan memicu keberhasilan produksi maggot. Nutrisi salah satu faktor yang berpengaruh pada komposisi pakan alami dan sangat penting untuk mendapatkan nilai produktivitas maggot yang tinggi di sertai dengan kualitas biomassa yang baik.

Dari Gambar 2. Berdasarkan hasil analisis keragaman ANOVA terhadap pertumbuhan populasi maggot menunjukkan bahwa $\mathrm{F}_{\text {hitung }}=53,89>\mathrm{F}_{\text {tabel }} 1 \%=10,92$, menunjukkan berbeda nyata. Sehingga keputusan yang di ambil menerima $\mathrm{H}_{1}$ dan menolak $\mathrm{H}_{0}$ yang berarti pertumbuhan maggot dengan komposisi yang berbeda berpengaruh sangat nyata di mana jumlah berat rata-rata perlakuan $\mathrm{A}=80,6$ gram, perlakuan $\mathrm{B}=63,2$ gram, dan perlakuan $\mathrm{C}=$ 37,6 gram. Hal ini terjadi karena adanya perbedaan komposisi dalam media pertumbuhan budidaya maggot, sehingga berpengaruh terhadap perkembangbiakan maggot, Perlakuan A di pandang lebih baik dari perlakuan B, perlakuan B lebih baik dari perlakuan C.

Berdasarkan hasil uji Beda Nyata Terkecil (BNT 1\%) di peroleh nilai BNT $1 \%$ $=15,60$ sehingga dapat di simpulkan bahwa perlakuan A sangat berbeda nyata dengan perlakuan $\mathrm{B}$ dan $\mathrm{C}$, perlakuan $\mathrm{B}$ berbeda sangat nyata dengan perlakuan $\mathrm{C}$ dan perlakuan $\mathrm{C}$ berbeda sangat nyata dengan perlakuan B dan A. Dengan demikian perlakuan A memberikan hasil yang terbaik dengan menggunakan media apu-apu kering $5 \mathrm{~kg}$, dedak halus $5 \mathrm{~kg}$, baram 1,5 liter, madu 1 liter, dan 5 butir telur ayam.

Pemanfaatan Tumbuhan Apu-apu dan Maggot (Hermetia illucens) Sebagai Pakan Ikan

Pemanfaatan tumbuhan apu-apu (Pistia stratiotes) sebagai media tumbuh maggot cukup efektif karena keberadaan tumbuhan ini mudah di dapat dan seringkali tanaman air ini dianggap juga sebagai gulma oleh sebagian besar petani. Tanaman air apu-apu juga merupakan tanaman air yang disukai unggas dan ikan. Apu-apu (Pistia stratiotes) merupakan bahan baku pakan lokal dengan serat, nilai nutrien dan produksi biomassa bahan kering yang cukup tinggi. Maggot ini akan mereduksi nutrient yang terdapat di media sebesar 50-70\% (Gary, 2009)

Maggot banyak digunakan sebagai pakan pada ikan-ikan air tawar seperti ikan patin, ikan toman, ikan lele, ikan arwana serta ikan lainnya. Maggot yang diberikan dapat berupa maggot segar maupun maggot yang telah dihancurkan. Maggot digunakan sebagai bahan baku pakan pengganti tepung ikan. Beberapa keuntungan maggot sebagai pakan ikan yaitu mudah dibudidayakan karena maggot mampu memanfaatkan bahan organik (limbah), dapat dibudidayakan secara massal, mengandung antimikroba, anti jamur, dan tidak membawa penyakit.

Kandungan protein dari maggot cukup tinggi yaitu sekitar 40\%. Oliver (2004) melaporkan bahwa larva BSF mengandung $42 \%$ protein. Selanjutnya Songbesan et. al. (2007) menyebutkan bahwa protein dari maggot dapat mencapai 50\%. Melihat hal tersebut, penggunaan maggot sebagai pakan ikan cukup menguntungkan karena untuk mendapatkan pakan alami berprotein tinggi 
dapat dilakukan dengan memproduksi maggot pada media tumbuh yang optimal.

Maggot sebagai pakan ikan dapat dimanfaatkan langsung berupa maggot yang masih hidup atau dibuat tepung maggot sebagai sumber protein pakan untuk menggantikan tepung ikan. Di lihat dari proses produksi untuk mendapatkan maggot cukup mudah dan relatif singkat maka maggot cukup prospek untuk di kembangkan. Hasil penelitian penggunaan maggot sebagai substitusi pakan komersial juga di laporkan oleh beberapa peneliti dimana maggot dapat menggantikan $50 \%$ pakan komersial pada ikan lele (Hadadi, 2007).

\section{KESIMPULAN}

Pemanfaatan tumbuhan apu-apu sebagai media tumbuh maggot berdasarkan hasil penelitian menunjukan bahwa perlakuan A lebih tinggi jumlah populasi maggot yaitu 645 ekor dan berat rata-rata 80,6 gram dengan komposisi apu-apu kering $5 \mathrm{~kg}$, dedak $5 \mathrm{~kg}$, baram 1,5 liter, madu 1 liter dan 5 butir telur ayam. Nilai keragaman ANOVA dari ketiga perlakukan menunjukkan adanya perbedaan yang sangat nyata untuk pertumbuhan populasi maggot, dengan suhu media rata-rata $37,6^{\circ} \mathrm{C}$. Berdasarkan hasil uji kandungan proksimat maggot yang telah dibuat menjadi tepung maggot memiliki kandungan air 0,96\%, protein $50,34 \%$, dan lemak $40,92 \%$.

\section{DAFTAR PUSTAKA}

Azhir A., Harris H., Kusuma Haris R.B. 2017. Produksi dan Kandungan Nutrisi Maggot (Chrysomya megacephala) Menggunakan Komposisi Media Kultur Berbeda. Jurnal Ilmu-Ilmu Perikanan dan Budidaya Perairan. Vol 12 Nomor 1.

Duponte M.W. and Larish L.B. 2003. Tropical Agriculture and Human Resources (CTAHR). Hawaii.
Gary. 2009. Black soldier fly larva. http://www.microponics.net [1 Maret 2011].

Handajani, H. 2011. Optimalisasi Substitusi Tepung Azolla Terfermentasi Pada Pakan Ikan Untuk Meningkatkan Produktivitas Ikan Nila Gift. Jurnal Teknik Industri, 12 (2): 177-181.

Hadadi. A., 2007. Aplikasi Pemberian Maggot Sebagai Sumber Protein Dalam Pakan Ikan.

Murni R, Akmal, Suparjo, BL Ginting.. 2008. Pemanfaatan limbah sebagai bahan pakan ternak 3. Laboratorium Makanan Ternak, Fakultas Peternakan, Universitas Jambi.

Oliver P. A. 2004. The Bio-Conversion of Putrescent Wastes. ESR LLC. Washington. P. 1-90

Retnosari, D. 2007. Pengaruh Substitusi Tepung Ikan Oleh Tepung Belatung Terhadap Pertumbuhan Benih Nila (Oreochromis niloticus) Fakultas Perikanan dan Ilmu Kelautan, Universitas Padjajaran, Jatinagor, Bandung.

Sugianto D. 2007. Pengaruh Tingkat Pemberian Maggot Terhadap Pertumbuhan dan Efisiensi Pemberian Pakan Benih Ikan Gurame (Osphronemus gouramy). Departemen Budidaya Perairan, Fakultas Perikanan dan Ilmu Kelautan, Institut Pertanian Bogor.

Songbesan O. A., ND. Ajuau, A.A.A. Ugwumba and C.T Madu. 2005. Cost benefits of maggot meal as supplemented feed in the diets of + Hererobranchus longifilis $\mathrm{x} \hat{\mathrm{C}}$ Clarias gariepinus (Pisces clariidae) 16 hybrid fingerlings in outdoor concrete tan. 
Jounal of Industrial and Scientific Research, 3; 51-55

Yudhitstira, S. 2013. Pengaruh Penggunaan

Daun Apu-Apu (Pistia stratiotes) Hasil Fermentasi Aspergillus niger dalam Pakan Buatan Terhadap Pertumbuhan Benih Ikan Nilem (Osteochilus hasselti). Jurnal Akuatika Vol.VI No.2 (hal :118-127). 